\title{
Colorectal Tumor-Associated Peptides Vaccine IMA910
}

National Cancer Institute

\section{Source}

National Cancer Institute. Colorectal T umor-Associated Peptides Vaccine IMA910. NCI

Thesaurus. Code C79806.

A synthetic tumor-associated peptide (TUMAP)-based cancer vaccine directed ag ainst colorectal cancer with potential immunostimulatory and antineoplastic activities.

Synthetic colorectal tumor-associated peptides vaccine IMA910 contains 13 different synthetic TUMAPs, each of which represents a tumor associated antigen (TAA) specific for colorectal cancer. Upon administration, this agent may elicit a cytotoxic T-lymphocyte $(\mathrm{CTL})$ response against colorectal tumors expressing these TAAs, which may result in a reduction in colorectal tumor cell proliferation. 